\title{
Propagação de porta-enxerto de Prunus spp. por estaquia: efeito do genótipo, do estádio de desenvolvimento do ramo e tipo de estaca ${ }^{1}$
}

\author{
Gabriela Gerhardt da Rosa ${ }^{2 *}$, Ilisandra Zanandrea ${ }^{3}$, Newton Alex Mayer $^{4}$, Valmor João Bianchi ${ }^{2}$
}

10.1590/0034-737X201764010013

\section{RESUMO}

A propagação de porta-enxertos de pessegueiro por estaquia é vantajosa, sendo necessários estudos sobre o tipo de estaca que proporciona melhor enraizamento.O objetivo deste trabalho foi avaliar a influência do estádio de desenvolvimento do ramo (herbáceo ou semilenhoso) e do tipo de estaca (basal ou apical) sobre o enraizamento adventício de quatro porta-enxertos de Prunus spp., dos cultivares 'Okinawa', 'Tsukuba-1' (Prunus persica L. Bastsch), 'Julior' (P. insititia L. x P. domestica L.) e 'Mirabolano 29-C' (P. cerasifera Ehrh). Em cada tratamento, estacas com $15 \mathrm{~cm}$, mantendo-se um par de folhas inteiras no seu ápice, foram preparadas e acondicionadas em vermiculita fina e mantidas sob nebulização intermitente, por 50 dias. Observou-se que, tanto nas estacas herbáceas como nas semilenhosas, as percentagens de enraizamento dos cultivares 'Mirabolano 29-C', 'Tsukuba-1' e 'Okinawa' foram superiores a 80\%. Quanto às estacas apicais, as maiores percentagens de enraizamento foram observadas para o cultivar 'Mirabolano 29C', que apresentou também maior número e maior massa seca de raízes. Em relação à parte aérea, 'Mirabolano 29-C' teve 96,65\% de estacas brotadas, com maior número e maior massa seca das brotações, seguido por 'Tsukuba-1', com 66,7\% de estacas brotadas. O cultivar 'Julior' apresentou os menores valores para todas as variáveis analisadas. 'Mirabolano 29-C' destacou-se entre os genótipos estudados, comprovando que principalmente o fator genótipo, mais do que o tipo de ramo e o tipo de estaca, pode ser determinante no sucesso da propagação de porta-enxertos de Prunus spp.

Palavras-chave: Prunus cerasifera Ehrh; Prunus persica L. Bastsch; P. insititia L. x P. domestica L.; enraizamento; estaca herbácea; estaca semilenhosa.

\section{ABSTRACT \\ Propagation of Prunus spp. rootstocks by cutting: effects of genotype, branch developmental stage, and cutting type}

The objective of this study was to evaluate the influence of branch developmental stage (herbaceous and semiwoody) and cutting type (basal and apical) on adventitious rooting of four Prunus spp. rootstock cultivars: 'Okinawa', 'Tsukuba-1' (Prunus persica), 'Julior' (P. insititia x P. domestica), and 'Mirabolano 29-C' (P. cerasifera). For each treatment, $15 \mathrm{~cm}$-long cuttings, with a pair of entire leaves at distal portion, were prepared. Cuttings were kept on vermiculite under intermittent mist system for 50 days. For both herbaceous or semi-hardwood cuttings, rooting percentages were higher than $80 \%$ for Mirabolano 29-C, Tsukuba-1, and Okinawa; however, apical cutting percentage was always highest for cv. Mirabolano 29-C, which also had the highest number and highest dry weight of roots. Mirabolano 29-C had $96.65 \%$ of sprouting, with the highest dry mass and number of new sprouts per cutting, followed by Tsukuba-1 with $66.7 \%$ sprouting. The cv. Julior showed the lowest values for all analyzed variables. Mirabolano 29-

\footnotetext{
Submetido em 08/09/2014 e aprovado em 19/12/2016.

Este trabalho é parte da dissertação de mestrado da primeira autora.

${ }^{2}$ Universidade Federal de Pelotas, Departamento de Botânica, Capão do Leão, Rio Grande do Sul, Brasil. birela89@gmail.com; valmorjb@yahoo.com

${ }^{3}$ Universidade Federal de Pelotas, Departamento de Botânica, Capão do Leão, Rio Grande do Sul, Brasil. Bolsista de Pós-Doutorado PNPD. dandajs@gmail.com

${ }^{4}$ Empresa Brasileira de Pesquisa Agropecuária, Pelotas, Rio Grande do Sul, Brasil. alex.mayer@embrapa.br

*Autora para correspondência: birela89@gmail.com
} 
C rootstock stood out among the studied genotypes, corroborating that genotype could be more important than branch or cutting type for the successful vegetative propagation of Prunus spp. rootstocks.

Key words: Prunus cerasifera; Prunus persica; P. insititia x P. domestica; rooting; herbaceous cutting; semihardwood cutting.

\section{INTRODUÇÃO}

No Brasil, embora não existam dados oficiais sobre a quantidade de mudas de Prunoideas produzidas anualmente, estima-se que seja de, pelo menos, 2,5 milhões de mudas de pessegueiro, nectarineira e ameixeira (Mayer \& Antunes, 2010). Apesar da importância econômica do setor de viveiros para a persicultura brasileira, na produção dos porta-enxertos, o sistema predominante ainda é o uso de sementes, o que promove variabilidade genética e diferenças de vigor e de comportamento entre as plantas nos futuros pomares.

$\mathrm{Na}$ fruticultura moderna, o uso de mudas com padrão de qualidade genética e sanitária constitui a base do pomar. Diversos trabalhos têm comprovado a importância da escolha do porta-enxerto, por sua influência sobre o vigor da planta, a qualidade do fruto e a produtividade do pomar (Ribas et al., 2007; Rocha et al., 2007; Picolotto et al., 2009; Schimitz et al., 2012). Entretanto, na região sul do Rio Grande do Sul (RS), principal polo produtor de frutas e mudas de Prunáceas, alguns fatores ainda limitam a produção de mudas com qualidade genética e a produtividade dos pomares. Dentre eles, destaca-se a forma de propagação dos porta-enxertos utilizados na produção das mudas (Fachinello et al., 2000; Schimitz et al., 2012).

No RS, a obtenção dos porta-enxertos é realizada, na sua grande maioria, a partir de caroços de cultivares-copa, obtidos nas indústrias de conserva, sendo que as plântulas obtidas (futuros porta-enxertos) não atendem às exigências mínimas de qualidade, por causa da mistura varietal (Rocha et al., 2007; Schimitz et al., 2012), resultando em problemas relacionados com as diferentes reações das plantas a patógenos do solo e a estresses abióticos, a desuniformidade das plantas e a redução da vida útil dos pomares (Tofanelli et al., 2002; Mayer et al., 2005; Mayer \& Antunes, 2010), uma vez que os cultivares-copa foram selecionados em função da produção e da qualidade de seus frutos e não para a obtenção de porta-enxerto (Mayer \& Antunes, 2010).

Por essa razão, a propagação de porta-enxertos pela técnica de estaquia tem como vantagens a facilidade de execução e a redução do tempo necessário à produção da muda, evitando a variabilidade genética (Tofanelli et al.,
2002; Mindello Neto, 2006). No Brasil, esta técnica vem sendo estudada há vários anos na cultura do pessegueiro. No entanto, a baixa taxa de enraizamento dos cultivares e as condições testadas têm sido limitantes para uso comercial (Tofanelli et al., 2002 e 2003). Segundo Hoffmann et al. (2003), este cenário está associado à necessidade de investimentos em infraestrutura para propagação, visando a melhorar as taxas de enraizamento, de sobrevivência e de crescimento rápido dos porta-enxertos para a realização de enxertia, que compensem a substituição dos porta-enxertos obtidos por sementes.

Além das características genéticas do cultivar, a capacidade de uma estaca de emitir raízes é função das condições ambientais proporcionadas ao enraizamento e de fatores endógenos da estaca, relacionados com o estado nutricional da planta matriz, à quantidade de carboidratos e aos reguladores de crescimento, fundamentais para a indução e o crescimento das raízes (Hartmann et al., 2002; Oliveira et al., 2012).

O tipo de estaca a ser utilizado na produção de mudas também influencia o enraizamento e varia com a espécie e o cultivar. Como a composição química do tecido varia, estacas provenientes de diferentes porções do ramo tendem a diferir quanto ao potencial de enraizamento (Hartmann et al., 2002). Diante disso, o objetivo deste trabalho foi avaliar o efeito do estádio de desenvolvimento do ramo e do tipo de estaca (basal e apical) no enraizamento adventício de estacas dos porta-enxertos 'Okinawa', 'Tsukuba-1', 'Julior' e 'Mirabolano 29-C'.

\section{MATERIAL E MÉTODOS}

O trabalho foi conduzido em casa de vegetação, utilizando-se material vegetal proveniente de plantas matrizes da "Coleção porta-enxerto de Prunus", da Embrapa Clima Temperado, mantida em condição de campo e sem irrigação.

Para o experimento, foram utilizadas os seguintes cultivares: 1/2Okinawa $1 / 4$ e 1/2Tsukuba-11/4 [Prunus persica (L.) Batsch - pessegueiro], 'Mirabolano 29-C' (P. cerasifera Earh- ameixeira) e 'Julior' (P. insititia L. x P. domestica L. - ameixeira). As plantas matrizes foram submetidas à poda drástica de inverno em 2012, cortando-se todas as pernadas a uma altura entre $1 \mathrm{~m}$ e $1,2 \mathrm{~m}$, objetivando estimular brotação intensa, vigorosa e padronizada. 
Em novembro de 2012, realizou-se a coleta de ramos herbáceos (experimento 1) e, em janeiro de 2013, a segunda coleta, constituída de ramos semilenhosos (experimento 2). Os ramos foram levados imediatamente para câmara de nebulização intermitente, instalada no interior de uma estufa agrícola tipo arco, de 24 x $8 \mathrm{~m}$, com teto em polietileno transparente e laterais com tela antiafídeos. O sistema de nebulização foi coberto com tela refletora Aluminet Polysack retrátil, para reduzir a radiação solar.

Estacas com aproximadamente $0,7 \mathrm{~cm}$ de diâmetro, com um par de folhas inteiras na parte apical, foram preparadas com $15 \mathrm{~cm}$ de comprimento, sendo a base cortada transversalmente (imediatamente abaixo de um nó) e, o ápice, em bisel. Na base da estaca, foram feitas duas lesões opostas $( \pm 3 \mathrm{~cm})$, a fim de expor o câmbio vascular. As estacas foram acondicionadas em caixas plásticas perfuradas, de $50 \times 30 \times 18 \mathrm{~cm}$, com vermiculita de granulometria fina, mantidas em bancadas de ferro galvanizado. O sistema de nebulização intermitente foi controlado por temporizador, programado para nebulizar durante dez segundos a cada intervalo de três minutos, durante todo o período do experimento.

Ambos os experimentos foram avaliados aos 50 dias após a instalação, removendo-se manual e cuidadosamente as estacas. As seguintes variáveis foram mensuradas: percentagem de estacas brotadas, número de brotações por estaca, comprimento da maior brotação $(\mathrm{cm})$, massa seca das brotações $(\mathrm{g})$, percentagem de estacas com calo, percentagem de enraizamento, número de raízes por estaca, comprimento médio das três maiores raízes $(\mathrm{cm})$ e massa seca das raízes (g). As massas secas das brotações e das raízes foram obtidas após a secagem em estufa (60 ${ }^{\circ} \mathrm{C}$ ), até massa constante. Os dados de percentagens foram transformados para arcsen $\left.\left(\sqrt{x^{1 / 2}}\right) / 100\right)$ e, os de contagens, para $\log (\mathrm{x}+0,5)$.

O delineamento experimental utilizado foi o inteiramente casualizado, em esquema fatorial 4 x 2 (porta-enxertos $\mathrm{x}$ tipo de estaca - basal ou apical), no experimento 1 (estacas herbáceas) e no experimento 2 (estacas semilenhosas). Cada tratamento foi composto por quatro repetições, sendo cada parcela composta por 15 estacas. Em cada caixa, foram instaladas duas parcelas. Realizou-se a análise de variância dos dados e, quando significativas $(\mathrm{p}>0,05)$, a comparação das médias pelo teste de Tukey $(\alpha<0,05)$, com o software Sisvar (Ferreira, 2008).

\section{RESULTADOS}

\section{Dados de enraizamento das estacas herbáceas}

$\mathrm{Na}$ análise de variância dos dados para as variáveis comprimento das raízes e percentagem de estacas com brotações, observou-se efeito significativo para tipo de estaca e cultivar, isoladamente. Houve interação entre os fatores apenas para a variável massa seca das raízes. Para percentagem de enraizamento, número de raízes, número de brotações e massa seca das brotações, registrou-se efeito significativo apenas do fator cultivar.

A percentagem média de estacas enraizadas foi maior para o cultivar Mirabolano 29-C (73,3\%). A porção apical do ramo teve uma taxa de enraizamento $32 \%$ maior que a porção basal, embora não tenha ocorrido interação entre fatores. Nesse cultivar, também se registrou o maior número de raízes por estaca $(11,08)$, independentemente da posição no ramo (Tabela 1). Quando avaliados os portaenxertos de pessegueiro Okinawa e Tsukuba-1, observouse média de 2,6 raízes por estaca, não havendo diferença estatística significativa entre eles (Tabela 1).

Para o comprimento médio das três maiores raízes, os maiores valores foram observados para os cultivares Mirabolano 29-C (8,97 cm) e Tsukuba-1 $(8,15 \mathrm{~cm})$. Por outro lado, as estacas da porção apical do ramo apresentaram comprimento médio das raízes maior do que as estacas da porção basal $(6,7 \mathrm{~cm}$ e $4,3 \mathrm{~cm}$, respectivamente Tabela 1).

O cultivar Julior apresentou somente 7,5\% das estacas enraizadas, o menor número de raízes por estaca $(0,11)$ e o menor comprimento médio dessas raízes $(0,07 \mathrm{~cm})$. A massa seca das raízes emitidas pelas estacas apicais dos cultivares Mirabolano 29-C e Tsukuba-1 foi 1,0 e 0,89 g, respectivamente, enquanto, nas basais, foi 0,26 e $0,3 \mathrm{~g}$, respectivamente (Tabela 2 ).

Em relação aos parâmetros avaliados na parte aérea, foram obtidas $96,65 \%$ de estacas brotadas do cultivar Mirabolano 29-C, com média de 1,71 brotações e massa seca de 3,29 g, não diferindo de Tsukuba-1, que apresentou $66,7 \%$ de estacas brotadas 1,28 brotações por estaca e $1 \mathrm{~g}$ de massa seca. O cultivar Julior apresentou somente 13\% das estacas com brotações, com média de 0,55 brotos por estaca. As estacas retiradas da porção basal do ramo apresentaram maior número de brotações, menores, no entanto, do que aquelas das estacas apicais, como pode ser comprovado pela massa seca daquelas (Tabela 3).

Com os cultivares Mirabolano 29-C e Tsukuba-1 registraram-se os melhores resultados de enraizamento e, além disso, não se observou a presença de calos na base das estacas apicais nem das basais (Dados não apresentados).

\section{Dados de enraizamento das estacas semilenhosas}

Verificou-se interação entre os fatores para percentagem de estacas enraizadas, número de raízes por estaca, comprimento e massa seca das raízes, estacas com brotações e número de brotações por estaca, enquanto para a variável massa seca das brotações verificou-se efeito significativo apenas do fator cultivar. 
As maiores percentagens de enraizamento, $(96,67 \%$, nas estacas apicais, e 76,67\%, nas basais), foram registradas com o cultivar Mirabolano 29-C, que também apresentou maior número, maior comprimento e maior massa seca das raízes, chegando à média de 12,76 raízes por estaca, com $8,10 \mathrm{~cm}$ e $1,24 \mathrm{~g}$ por estaca da porção apical e 8,36 raízes, com 5,68 cm e 0,2 g por estaca, das basais (Tabela 4 ).

Mirabolano 29-C, que apresentou a maior percentagem de enraizamento, teve menor percentagem de estacas com formação de calo que Okinawa e Tsukuba-1, percentagens essas que chegaram a 28,33 e 14,16\%, respectivamente (dados não apresentados).

O cultivar Mirabolano 29-C apresentou a maior percentagem de estacas com brotações, chegando a 93,33\%, nas estacas apicais, e 98,33\%, nas basais. A percentagem de estacas brotadas de Mirabolano 29-C foi $86,6 \%$ superior à média das estacas apicais brotadas e $67,4 \%$ superior às basais brotadas (Tabela 4). Somado a isso, Mirabolano 29-C apresentou 2,48 brotos nas estacas apicais e 2,88 brotos nas estacas basais, valores bem acima da média quando comparados com os dos outros três cultivares, tanto para estacas apicais como basais, apresentando uma média de 2,68 brotações por estaca (Tabela 4), sendo que esse mesmo cultivar também apresentou a maior média de massa seca das brotações com 1,72 g (Tabela 5).

\section{DISCUSSÃO}

Com base nos resultados obtidos, verificou-se que as respostas das estacas ao enraizamento, em ambos os experimentos, variaram em função da posição do ramo em que foram retiradas, mas principalmente por efeito do genótipo, conforme pode ser observado nas Tabelas 1 e 4. Para que o enraizamento seja bem sucedido, é necessário que ocorra o transporte polar basípeto de auxina, que é produzida nas folhas jovens e nas gemas das brotações. Esse transporte direciona o hormônio para a base da esta- ca, promovendo a formação das raízes. Nas raízes, o transporte torna-se acrópeto, sendo a auxina transportada da base da estaca para o ápice da raiz, propiciando, assim, o seu alongamento (Mindello Neto, 2006; Sulusoglu \& Cavusoglu, 2010).

A auxina age como um ativador de genes que promovem a diferenciação celular para formar o primórdio radicular. Diversos autores comprovaram a necessidade de utilizar auxinas exógenas para obter percentagens satisfatórias de enraizamento em estacas de porta-enxertos de Prunus spp. (Tofanelli et al., 2002 e 2003; Mindello Neto, 2006; Ribas et al., 2007; Exadaktylou et al., 2009). Esta aplicação favorece a conjugação com aminoácidos que promovem a síntese de proteínas específicas, necessárias para a formação de raízes iniciais (Han et al., 2009). Embora esse favorecimento ocorra, fatores como potencial genético do cultivar, balanço hormonal endógeno e consistência dos tecidos das estacas (maior ou menor espessura do anel de esclerênquima) são primordiais para o desenvolvimento das raízes. Além disso, a condição fisiológica da planta matriz, determinada pelas características e pelo manejo do solo, pode influenciar na capacidade de formação das raízes na estaca (Tofanelli et al., 2002).

Neste ensaio, quando utilizadas estacas provenientes da porção apical dos ramos herbáceos, observaram-se al-

Tabela 2: Efeito do genótipo e do tipo de estaca dos portaenxertos de ameixeira 'Julior' $(P$. insititia $\times P$. domestica), 'Mirabolano 29-C (P. cerasifera) e de pessegueiro 'Okinawa' e 'Tsukuba-1' ( $P$. persica) na massa seca das raízes de estacas herbáceas

\begin{tabular}{lcc}
\hline Porta-enxerto & Apical & Basal \\
\hline Julior & $0,00 \mathrm{bA}$ & $0,03 \mathrm{aA}$ \\
Mirabolano 29-C & $0,89 \mathrm{aA}$ & $0,26 \mathrm{aB}$ \\
Okinawa & $0,34 \mathrm{bA}$ & $0,09 \mathrm{aA}$ \\
Tsukuba-1 & $1,01 \mathrm{aA}$ & $0,30 \mathrm{aB}$
\end{tabular}

Médias seguidas pela mesma letra minúscula na coluna e maiúscula na linha não diferem entre si pelo teste de Tukey $(\alpha<0,05)$.

Tabela 1: Efeito do genótipo e do tipo de estaca dos porta-enxertos de ameixeira 'Julior' (P. insititia x P. domestica), 'Mirabolano 29C ( $P$. cerasifera $)$ e de pessegueiro 'Okinawa' e 'Tsukuba-1' $(P$. persica $)$ na percentagem de estacas enraizadas, número de raízes por estaca e comprimento médio das três maiores raízes em estacas herbáceas

\begin{tabular}{lccc}
\hline Porta-enxerto & $\begin{array}{c}\text { Estacas Enraizadas } \\
(\boldsymbol{\%})\end{array}$ & $\begin{array}{c}\text { Raízes por Estaca } \\
\left(\mathbf{n}^{\mathbf{0}}\right)\end{array}$ & $\begin{array}{c}\text { Comprimento Médio das } \\
\text { três Maiores Raízes }(\mathbf{c m})\end{array}$ \\
\hline Julior & $7,50 \mathrm{c}$ & $0,11 \mathrm{c}$ & $0,07 \mathrm{c}$ \\
Mirabolano 29-C & $73,33 \mathrm{a}$ & $11,08 \mathrm{a}$ & $8,97 \mathrm{a}$ \\
Okinawa & $34,17 \mathrm{~b}$ & $2,21 \mathrm{~b}$ & $4,83 \mathrm{~b}$ \\
Tsukuba-1 & $55,83 \mathrm{ab}$ & $3,084 \mathrm{~b}$ & $8,15 \mathrm{a}$ \\
\hline Posição & Estacas Enraizadas & Raízes por Estaca & Comprimento Médio das \\
& $(\boldsymbol{\%})$ & $\left(\mathbf{n}^{\mathbf{0}}\right)$ & três Maiores Raízes (cm) \\
\hline Apical & 50,83 & 4,10 & $6,69 \mathrm{a}$ \\
Basal & 34,58 & 4,15 & $4,32 \mathrm{~b}$ \\
\hline
\end{tabular}

Médias seguidas pela mesma letra, na coluna, não diferem entre si pelo teste de Tukey $(\alpha<0,05)$. 
tas taxas de enraizamento dos cultivares Mirabolano 29C, Okinawa e Tsukuba-1, mesmo sem a utilização de auxina exógena (Tabelas 1 e 4). Em contrapartida, o cultivar Julior apresentou baixo índice de enraizamento, provavelmente por ter apresentado, na maioria das estacas, a formação de calos (dados não apresentados), demonstrando a possível necessidade de aplicação de auxina exógena. Resultados semelhantes foram observados por Sulusoglu \& Cavusoglu (2010), ao avaliarem estacas semilenhosas de cerejeira (Prunus laurocerasus L.), que apresentaram percentagem média de $54 \%$ de enraizamento, 10,3 raízes por estaca com 5,2 cm de comprimento, mesmo sem a utilização de auxina exógena. Por outro lado, Tofanelli et al. (2002), trabalhando com estacas semilenhosas de pessegueiro, sem a utilização de auxina exógena, com dois cultivares de porta-enxertos e dez cultivares-copa, com idade entre seis e sete anos em condições de campo, observaram um potencial de enraizamento praticamente nulo $(0,68 \%)$ com 0,10 raiz por estaca. Feldberg et al. (2010) obtiveram somente $11,4 \%$ de enraizamento de estacas semilenhosas de pereira (Pyrus spp.), 1,29 raiz por estaca e média de $2,14 \mathrm{~cm}$, quando não utilizada auxina exógena na indução do enraizamento.

Sabe-se que o enraizamento pode ser influenciado por diversos fatores, como tipo de estaca e época do ano (Tofanelli et. al., 2002). A época de coleta dos ramos para o preparo das estacas está relacionada com o teor de lignificação dos ramos, pois, de acordo com o grau de lignificação das estacas, elas tendem a variar o seu estado de turgidez, influenciando o transporte de substâncias e o enraizamento adventício. Desta forma, foi possível observar neste ensaio que a maior média de enraizamento ocorreu em estacas apicais, sendo 50,83\% para estacas herbáceas e 86,25\% para as semilenhosas (Tabelas 1 e 4). Esses resultados assemelham-se aos encontrados por Exadaktylou et al. (2009), em trabalho realizado com o portaenxerto de cerejeira do cultivar 'GiSeLa', na época do ano em que as estacas encontravam-se lenhosas, obtendo-se
$31 \%$ de enraizamento, quando utilizadas estacas retiradas da porção apical do ramo e tratadas com solução de 1 $\mathrm{g} \mathrm{L}^{-1}$ de AIB. A taxa de enraizamento foi de apenas $12 \%$ quando não foi utilizado regulador de crescimento exógeno. Portanto, pode-se dizer que, tanto os resultados observados neste ensaio quanto no ensaio realizado por Exadaktylou et al. (2009), mostram que no período em que as estacas são herbáceas e a planta está em crescimento mais ativo, há maior disponibilidade de auxina livre, sendo o seu transporte facilitado para a parte basal da estaca, estimulando a formação das raízes. Em contrapartida, em estacas semilenhosas há a tendência de existirem maiores níveis de AIA na forma conjugada, o que dificulta o seu transporte e a sua utilização pelas plantas (Blakesley et al., 1991).

Hartmann et al. (2002) sugerem que materiais com menor grau de lignificação, como é o das estacas apicais, apresentam condições fisiológicas adequadas para a emissão de raízes adventícias. Estacas com grau elevado de lignificação, como é o caso das retiradas da porção basal, tendem a ter níveis mais baixos de auxina, pois, nelas, enzimas como as peroxidases estão envolvidas na síntese de lignina e na degradação de auxinas. Para Canli \& Bozkurt (2009), a maior dificuldade na formação de raízes adventícias em estacas pode ser devida à incapacidade da planta matriz de sintetizar auxina.

Na produção de mudas em escala comercial, o sistema radicular bem formado favorece a absorção de nutrientes e de água, propiciando, desta forma, melhor desenvolvimento da muda, depois de transplantada para o campo (Cardoso et al., 2011). No ensaio realizado, isso foi observado no cultivar Mirabolano 29-C, que apresentou maior emissão e maior comprimento das raízes. Alem disso, Feldberg et al. (2010) enfatizam a importância de avaliar variáveis relacionadas com o enraizamento, como o número de raízes por estaca e o comprimento médio das três maiores raízes, pois esses parâmetros, juntamente com a percentagem de enraizamento, revelam a qualidade do sis-

Tabela 3: Efeito do genótipo e do tipo de estaca dos porta-enxertos de ameixeira 'Julior' ( $P$. insititia x P. domestica), 'Mirabolano 29C (P. cerasifera) e de pessegueiro 'Okinawa' e 'Tsukuba-1' $(P$. persica) na percentagem de estacas brotadas, número médio de brotações por estaca e massa seca das brotações, de estacas herbáceas

\begin{tabular}{lccc}
\hline Porta-enxerto & $\begin{array}{c}\text { Estacas Brotadas } \\
(\boldsymbol{\%})\end{array}$ & $\begin{array}{c}\text { Número de Brotos } \\
\text { por Estaca }\left(\mathbf{n}^{\mathbf{0}}\right)\end{array}$ & $\begin{array}{c}\text { Massa Seca das } \\
\text { Brotações }(\mathbf{g})\end{array}$ \\
\hline Julior & $13,32 \mathrm{~b}$ & $0,55 \mathrm{~b}$ & $0,03 \mathrm{~b}$ \\
Mirabolano 29-C & $96,65 \mathrm{a}$ & $1,71 \mathrm{a}$ & $3,29 \mathrm{a}$ \\
Okinawa & $28,32 \mathrm{~b}$ & $1,23 \mathrm{a}$ & $0,83 \mathrm{~b}$ \\
Tsukuba-1 & $66,66 \mathrm{a}$ & $1,28 \mathrm{a}$ & $1,04 \mathrm{~b}$ \\
\hline Posição & Estacas Brotadas & Número de Brotos & Massa Seca das \\
\hline Apical & $\mathbf{( \% )}$ & por Estaca $\left(\mathbf{n}^{\mathbf{0}}\right)$ & Brotações $(\mathbf{g})$ \\
Basal & $3,74 \mathrm{~b}$ & $1,15 \mathrm{~b}$ & 1,50 \\
\hline
\end{tabular}

Médias seguidas pela mesma letra na coluna não diferem entre si pelo teste de Tukey $(\alpha<0,05)$ 


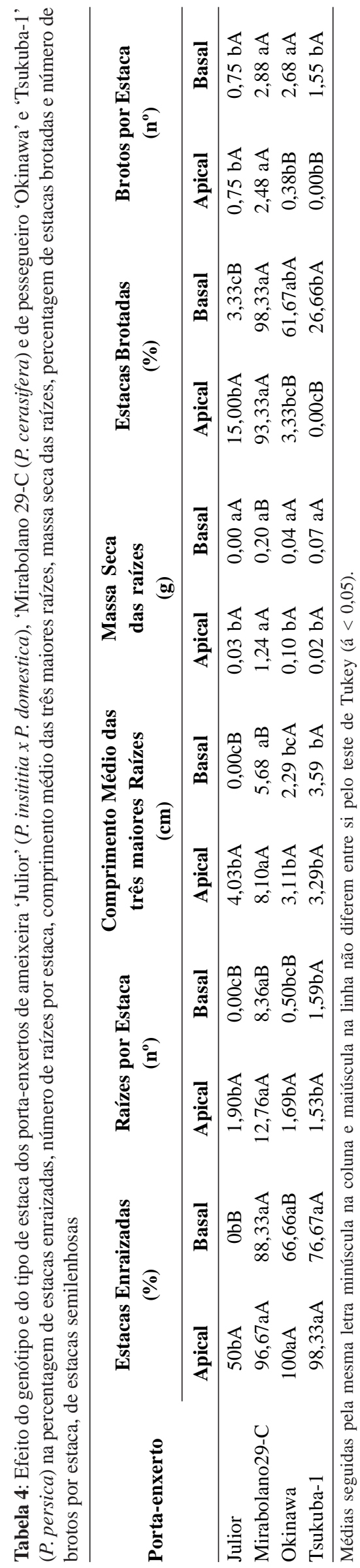

tema radicular e a capacidade de sobrevivência das estacas, após a retirada da câmara de nebulização, quando ocorrem a aclimatação e o crescimento. Posteriormente, essas variáveis também influenciarão no crescimento dos porta-enxertos, no engrossamento do caule, na época de realização da enxertia, no crescimento e na ancoragem das plantas no campo.

De acordo com os resultados obtidos, foi possível observar que com os cultivares Okinawa e Julior, que apresentaram as menores percentagens de enraizamento, foram obtidos os maiores índices de formação de calos na base das estacas. Segundo Oliveira et al. (2012), a formação de calos na base das estacas ocorre pela intensa divisão celular, promovida pela alta concentração de auxina no local, oriunda do transporte celular basípeto, com o intuito de promover a cicatrização do corte e, além disso, a formação de calos, em alguns casos, pode funcionar como fase intermediária da formação das raízes.

Hartmann et al. (2002) e Han et al (2009) constataram que o excesso de calos pode impedir o enraizamento, podendo ainda ocorrer alterações do conteúdo de cofatores e acúmulo de inibidores do enraizamento, que nesse caso podem influenciar negativamente a formação das raízes. Canli \& Bozkurt (2009), em estudo realizado com estacas semilenhosas de ameixeira, observaram que, quando não foi aplicado nenhum regulador de crescimento, as estacas apresentaram percentagem de formação de calos superior a $50 \%$ e a formação das raízes não foi necessariamente dependente da formação de calos, pois as raízes foram capazes de formar-se, na maioria das estacas, sem qualquer fase intermediária.

As variáveis relativas ao desenvolvimento da parte aérea das estacas, nas duas épocas de coleta, foram inversamente proporcionais às variáveis do enraizamento. Estacas retiradas da porção basal dos ramos apresentaram a maior percentagem de brotações e o maior número de brotos por estaca, enquanto estacas apicais apresen-

Tabela 5: Efeito do genótipo e do tipo de estaca dos portaenxertos de ameixeira 'Julior' ( $P$. insititia $\times$ P. domestica), 'Mirabolano 29-C (P. cerasifera) e de pessegueiro 'Okinawa' e 'Tsukuba-1' (P. persica) na massa seca das brotações de estacas semilenhosas

\begin{tabular}{|c|c|}
\hline Porta-enxerto & Massa Seca das Brotações (g) \\
\hline Julior & $0,05 b$ \\
\hline Mirabolano 29C & $1,72 \mathrm{a}$ \\
\hline Okinawa & $0,06 b$ \\
\hline Tsukuba-1 & $0,05 b$ \\
\hline Posição & Massa Seca das Brotações (g) \\
\hline Apical & 0,48 \\
\hline Basal & 0,47 \\
\hline
\end{tabular}


taram maior percentual de enraizamento, raízes em maior número e tamanho, além de maior massa seca do sistema radicular. A massa seca das brotações apresentou maiores valores quando as estacas foram retiradas da porção apical dos ramos, pelo fato de essas brotações serem maiores.

Em contrapartida, vários autores têm mostrado que a emissão simultânea de uma maior quantidade de raízes e de maiores brotações favorece o desenvolvimento das estacas, facilitando o crescimento e a condução adequada da planta no campo (Chagas et al., 2008). A presença de brotações e de folhas exerce forte influência estimulante sobre o enraizamento da estaca, pois permite a sobrevivência pela fotossíntese de carboidratos,, os quais atuam como fonte de energia e como elementos constitutivos para as novas células formadas, além do fornecimento de auxinas e outras substâncias importantes para a atividade cambial e a diferenciação celular (Haissig \& Davis, 1994).

Por essa razão, a manutenção das folhas nas estacas herbáceas e semilenhosas é necessária para a produção inicial de assimilados, auxiliando na formação de brotos e gemas que irão intensificar a síntese de carboidratos e de auxina. A manutenção dessas folhas torna-se possível graças ao ambiente em que as estacas foram mantidas, pois as gotículas de água da irrigação intermitente formam uma camada sobre a superfície das folhas, mantendo a sua umidade e fazendo que elas percam calor, possibilitando a fotossíntese, fenômeno observado principalmente, nos cultivares Mirabolano 29-C e Tsukuba-1, que mantiveram as folhas originais mais que Julior e Okinawa. Mayer et al. (2005) verificaram que a retenção de folhas nas estacas de umezeiro influencia a velocidade de enraizamento, enquanto a ausência de folhas resultou, quase sempre, em estacas com calo, ou mortas.

Pode-se observar que o enraizamento de estacas de pessegueiro e ameixeira, nas duas épocas de coleta dos ramos, pode ser realizado com sucesso, mesmo sem uso de regulador de crescimento. A resposta positiva dos genótipos ao ambiente de enraizamento é fator decisivo para a propagação por estaquia, pois verificou-se que alguns genótipos podem apresentar maior facilidade em se adaptar às condições da câmara de nebulização, principalmente. Mirabolano 29-C, por diferirem quanto à produção e exigência dos níveis hormonais para indução da rizogênese, como também na mobilização das reservas para o enraizamento e indução de novas brotações que mantêm a produção de auxina.

Todos estes processos são determinados pela expressão de genes codificados de acordo com as características de cada genótipo. Muitos genes são induzidos pela presença de auxina e são regulados pela interação de duas classes de fatores de transcrição: fatores de resposta à auxina e repressores de resposta à auxina (Aux / IAA). Quando a planta não tem a capacidade de sintetizar níveis adequados desse fitormônio e sua concentração está abaixo do limiar necessário, os repressores Aux / IAA associam-se aos ativadores, reprimindo a expressão desses genes, limitando o desenvolvimento das raízes adventícias. Por outro lado, quando a síntese de auxina na planta atinge os níveis necessários, ocorrem o bloqueio ou a destruição dos repressores Aux / IAA, seguido da ativação dos genes de resposta à auxina (Han et al., 2009).

Por essa razão, nota-se que o sucesso da propagação de porta-enxertos para a produção de mudas em escala comercial está associado à escolha do cultivar a ser propagado, bem como da posição do ramo em que a estaca for retirada. Sendo assim, embora neste trabalho não se tenha testado a interação genótipo x reguladores de crescimento, os resultados obtidos comprovam que o fator genético tem uma influência determinante no enraizamento. Somado a isso, ainda são necessários estudos complementares para a avaliação do comportamento desses porta-enxertos quanto à capacidade de aclimatação após o enraizamento e a transferência para o campo.

\section{CONCLUSÕES}

É tecnicamente possível a propagação dos porta-enxertos Mirabolano 29-C, Okinawa e Tsukuba-1, por estaquia herbácea e semilenhosa, sem a utilização de reguladores de crescimento.

O cultivar Mirabolano 29-C apresenta as maiores percentagens de enraizamento e de qualidade de raízes, tanto por estacas herbáceas $(73,33 \%)$ como por semilenhosas $(96,67 \%)$, oriundas da porção apical do ramo.

\section{REFERÊNCIAS BIBLIOGRÁFICAS}

Blakesley D, Weston GD \& Hall JF (1991) The role of endogenous auxin in root initiation. Plant Growth Regulation, 10:341-353.

Canli FA \& Bozkurt S (2009) Effects of Indolebutyric Acid on Adventitious Root Formation from semi-hardwood cuttings of 'Sarierik' plum. Journal of Applied Biological Sciences, 3:45-48.

Cardoso C, Yamamoto LY, Preti EA, Assis AM, Neves CSVJ \& Roberto SR (2011) AIB e substratos no enraizamento de estacas de pessegueiro 'Okinawa' coletadas no outono. Semina: Ciências Agrárias, 32:1307-1314.

Chagas EA, Pio R, Neto JEB, Sobierajski GR, Dall'orto FAC \& Signorini G (2008) Enraizamento de estacas lenhosas de pessegueiro e clones de umezeiros submetidos à aplicação de AIB. Ciência e Agrotecnologia, 32:986-991.

Exadaktylou E, Thomidis T, Grout B, Zakynthinos G \& Tsipouridis C (2009) Methods to improve the rooting of hardwood cutting of 'Gisela 5' cherry rootstock. HortTechnology, 2:254-259.

Fachinello JC, Silva CAP, Sperandio C, Rodrigues AC \& Strelow EZ (2000) Resistência de porta-enxertos para pessegueiro e ameixeira aos nematóides causadores de galhas (Meloidogyne spp.). Ciência Rural, 30:69-72. 
Feldberg NP, Barbosa W, Mayer NA \& Santos FMC (2010) Propagação vegetativa de porta-enxertos de pereira por estacas semilenhosas. Revista Ceres, 57:810-816.

Ferreira DF (2008) SISVAR: um programa para análises e ensino de estatística. Revista Symposium, 6:36-41.

Haissig BE \& Davis TD (1994) A historical evaluation of adventitious rooting research to 1993. In: Davis \& TD \& Haissig BE (Eds.) Biology of adventitious roots formation. New York, Plenum Press. p.275-331.

Han H, Zhang S \& Sun X (2009) A review on the molecular mechanism of plants rooting modulated by auxin. African Journal of Biotechnology, 8:348-353.

Hartmann HT, Kester DE \& Davis Junior FT (2002) Plant propagation: principles and practices. New Jersey, Prentice Hall. 880 p.

Hoffmann A, Nachtigal JC \& Bernardi J (2003) Sistema de produção de pêssego de mesa na região da serra gaúcha. Disponível em: <http://sistemasdeproducao.cnptia.embrapa.br/ FontesHTML/Pessego/PessegodeMesaRegiaoSerraGaucha/>. Acessado em: 24 de maio de 2014.

Mayer NA, Pereira FM \& Santos JM (2005) Resistência de clones de umezeiro e cultivares de pessegueiro a Meloidogyne incógnita (Nemata: Heteroderidae). Revista Brasileira de Fruticultura, 27:335-337.

Mayer NA \& Antunes LEC (2010) Diagnóstico do Sistema de Produção de Mudas de Prunóideas no Sul e Sudeste do Brasil Pelotas, Embrapa Clima Temperado. 52p. (Documentos, 293).

Mindello Neto UR (2006) Estaquia herbácea de pessegueiro cv. 'Charme', em função de diferentes concentrações de ácido indolbutírico (AIB) e números de folhas. Revista Brasileira de Agrociência, 12:27-29.
Oliveira RJP, Bianchi VJ, Aires RF \& Campos AD (2012) Teores de carboidratos em estacas lenhosas de mirtileiro. Revista Brasileira de Fruticultura, 34:1199-1207.

Picolotto L, Manica-Berto R, Pazin D, Pasa MS, Schmitz JD, Prezotto ME, Betemps D, Bianchi VJ \& Fachinello JC (2009) Características vegetativas, fenológicas e produtivas do pessegueiro cultivar Chimarrita enxertado em diferentes porta-enxertos. Pesquisa Agropecuária Brasileira, 44:583-589.

Ribas CP, Gomes FGD, Leonor R, Biasi LA \& Marçallo FA (2007) Ácido indolbutírico no enraizamento de estacas semilenhosas das cultivares de pessegueiro 'della nona' e 'eldorado'. Scientia Agraria, 8:439-442.

Rocha MDS, Bianchi VJ, Fachinello JC, Schmitz JD, Pasa MS \& Silva JB (2007) Comportamento agronômico inicial da cv. Chimarrita enxertada em cinco porta-enxertos de pessegueiro. Revista Brasileira de Fruticultura, 29:583-588.

Schimitz JD, Bianchi VJ, Pasa MS, Kulkamp AL \& Fachinello JC (2012) Vigor e produtividade do pessegueiro 'Chimarrita' sobre diferentes porta-enxertos. Revista Brasileira de Agrociência, 18:01-10

Sulusoglu M \& Cavusoglu A (2010) Vegetative propagation of Cherry laurei (Prunus laurocerasus L.) using semi-hardwood cuttings. African Journal of Agricultural Research, 5:3196-3202.

Tofanelli MBD, Chalfun NNJ, Hoffmann A \& Junio AC (2002) Efeito do ácido indolbutírico no enraizamento de ramos semilenhosos de pessegueiro. Pesquisa Agropecuária Brasileira, 37:939-944

Tofanelli MBD, Rodrigues JD \& Ono EO (2003) Método de aplicação de ácido indolbutírico no enraizamento de estacas herbáceas de pessegueiro. Revista Brasileira de Fruticultura, 25:363364. 